\title{
TRADITIONAL GAMES IN ESTONIA
}

\author{
Kaie JEESER ${ }^{1}$-Kalle VoOLAID ${ }^{1}-$ Marge VÄRV ${ }^{2}$ \\ ${ }^{1}$ Estonian Sports Museum, EE2400 Tartu, Riia 27a, Estonia \\ ${ }^{2}$ Estonian National Museum, EE2400 Tartu, Veski 32, Estonia
}

Estonians have been farmers through centuries. Due to this, hard farm work has been an essential part of their everyday lives since childhood and little time has been left for entertainment. In spite of that, Estonians have preserved a rich selection of traditional games often played even nowadays. The fact that games have continued to exist so long can be explained by their connection with traditional holidays in the folk calendar. Traditional holidays were the same from year to year and so were the traditional customs observed on certain days, e. g. straw was brought in at Christmas, fire was made on Midsummer Day, sliding downhill was connected with Shrove Tuesday, etc. Observing these traditions helped to preserve the games connected with them. At the beginning of this century when some of the old customs started to die out, many of the games were forgotten as well. However, there have been people in Estonia who popularised these games.

In Estonia the games (including also the folk games) have been studied mainly at the higher schools (Tartu University, Tallinn Pedagogical Institute), scientific institutions (the Estonian Language and Literature Institute [Tallinn-Tartu]) and Museums (the Estonian Literature Museum [Tartu], the Estonian National Museum [Tartu]). The largest collection of described folk games we can find in the folklore archives of the Literature Museum and the Estonian Sports Museum (Tartu).

One among the first who collected and popularised the folk games in Estonia was Anna RAUDKATS (1886-1965). RAUDKATS was one of the first gymnastics teachers who had higher education (in 1915 she graduated from the Gymnastics Institute at Helsinki University). The main favour of RAUDKATS was collecting and describing folk dances, but in the 30-s she also wrote several books with the descriptions of games. In her gymnastics lessons she used both folk dances and folk games.

In 1934-35 the first large collection of folk games came into being under the guidance of the Estonian National Museum and the Estonian Archives of Folklore as preparations began for the scientific publication of the Estonian folk games.

One initiator of this collection was Aleksander KALAMEES (1897-1987). He graduated from the Berlin University of Physical Education in 1925 and worked at Tartu University. The photos made during the collection work are preserved in the Department of Folklore of the Estonian Literature Museum and the photo collec- 
tion of the Estonian National Museum. In 1936 KALAMEES wrote a book, which for the first time described the Estonian folk games on a large scale.

Folk music researcher and folklorist Herbert TAMPERE (1909-1975) also studied games with songs. He wrote many articles and publications about Estonian folk music and music instruments, folk dances and songs including the plays with songs.

During the Soviet period Endel IsOP, Lecturer in Tallinn Pedagogical Institute, studied games (especially sport games). He is the author of several books about games.

Nowadays research work about folk games is carried out first of all in the Estonian Literature Museum. A special working group for this research has been formed there. Thanks to this, the collections of the museum have widened and the first scientific works are being completed.

It is always mainly children who play games. Adults take time for playing during holidays and parties when a larger company gathers (calendar holidays, wedding parties, finishing of bees, etc.).

On folk calendar holidays (Christmas, Shrove Tuesday, Easter) working was often prohibited, therefore it was usually time for people's gathering and merrymaking, at the same time being a short 'breathing space' at the end of some major working period before the next one was started (e. g. Midsummer Day - end of sowing time before hay making and harvesting, St. Michael's Day - end of fieldwork before threshing). It has been a long-time tradition in Estonia to slaughter a domestic animal on this occasion and have plenty to eat and drink because on weekdays meals were rather meagre. Beer was a compulsory item on the menu and stronger drinks were also consumed. This favoured joy for playing and testing the strength.

Christmas is the holiday with the longest and many-sided traditions. From St. Thomas's Day (December 21) people began preparing for Christmas - Christmas beer had to start brewing, feast food made ready, rooms cleaned. Holidays ended at Epiphany (January 6), in some places on St. Canute's Day (January 7) (HIIEMÄE 1991: 15,) and this day usually turned into men's gathering where the last barrel of beer was drunk.

The term Christmas was used by folk both for the holidays marking the birth of Christ and for the whole period of the midwinter holidays. As the period of Christmas is the end of the darkest period and the beginning of the new ecliptic, it is rich in several magical reproduction and protection traditions.

The real holidays began with bringing straw inside on Christmas Eve (December 24) (Collection E 67345). By that time all preparation works had to be finished. Future crop was predicted by playing on (and with) straw. It was also necessary to hurry to 'move' the agricultural implements, so one could succeed in summer works better than others.

The most popular games were hitting with a pass and shoemaker's game.

Hitting with a pass - players hit each other with a truss made of straw and called 'a pass' or 'a pat' (Collection E 72527).

Shoemaker's game - Three trusses are made of straw and tied up at one end. This is called 'the shoemaker'. 'The shoemaker' stands on the floor. One of the play- 
ers is next to it, the other comes riding on a broomstick and asks, whether the shoemaker was at home and would he make a pair of shoes for him. Getting a negative answer he says: Then I'll stab his eye. Both players straddle on a stick with their backs touching. One of them tries to knock 'the shoemaker' down, the other facing it tries to lead the stick aside (Collection E 757).

Several games requiring strength and skill (pulling a stick crosswise, pulling fingers, pulling yokes) were played also during other holidays, but for example catching ruff and licking of honey were typical of Christmas and needed a lot of skill.

Catching ruff - This game is widely known all over Estonia and has many versions. The player has to move by using his hands only, to an object, for example a truss of straw called 'a ruff', pick it up in his mouth and get back to his initial position. (Collection ERA II 89, 305).

Licking of honey - A rope is fixed with both ends up so that the centre is about $0.5 \mathrm{~m}$ from the ground. The player - 'honey licker' - sits on the rope, puts a stick between his stomach and rope, and begins to wind himself up by somersaulting forward. Up is hanging something the player has to touch with his nose, lick or bring down with his mouth. Afterwards the player comes down somersaulting again. (Collection ERA II 91, 490).

Masked people ran from house to house. During Christmas people usually masked themselves as geese, on New Year's Eve as bucks or bears, on Epiphany as storks. (HIIEMÄE 1991: 15). Most popular of these animals was New Year's buck. Inside-out fur-coat was put on and a whisk was used for tail. The masked person moved as a buck (on for feet) and played tricks on the others until he got some food (Collection E 67281).

In was necessary to eat much during Christmas time. Pork was the most important food. Special bread called "Christmas pig' was baked at the beginning and lasted till the end of the holidays. In some places Christmas pig was also a game - a man or a woman was disguised 'a Christmas pig' by stuffing straw or hay into his/her clothes to look like a fattened pig. 'The pig' tried to rebel against it, so there was much shouting and noise (Collection ERA II 91, 792).

Of winter holidays the most wide-spread and best-known also nowadays is Shrove Tuesday. Shrove Tuesday is a movable feast, new moon and Tuesday are required. The holiday is between February 08-March 07. Because of moving Shrove Tuesday has several old beliefs and customs, which often have derived from different periods. On Shrove Tuesday everybody had to go slide (Collection ERA II 263, 226) - it predicted good flax and hemp growth: the longer your slide, the longer your flax grew. Flax was for the Estonians an old and very needed culture. That is why there were many customs and magical traditions through which the Estonians tried to affect flax growth. It was necessary for the mother of household to be on slide. For better flax growth mainly the mother of household put a small purse filled with flax seeds under the seat (LÄTT 1970: 99). There were different ways for sliding which partly depended on climate, partly on landscape. Most often a sleigh without thills was pulled to the top of the hill (Fig. 1). Children did it in an easier way: when there was no sledge they used a bench turned round, a branch of a fir-tree or just their 


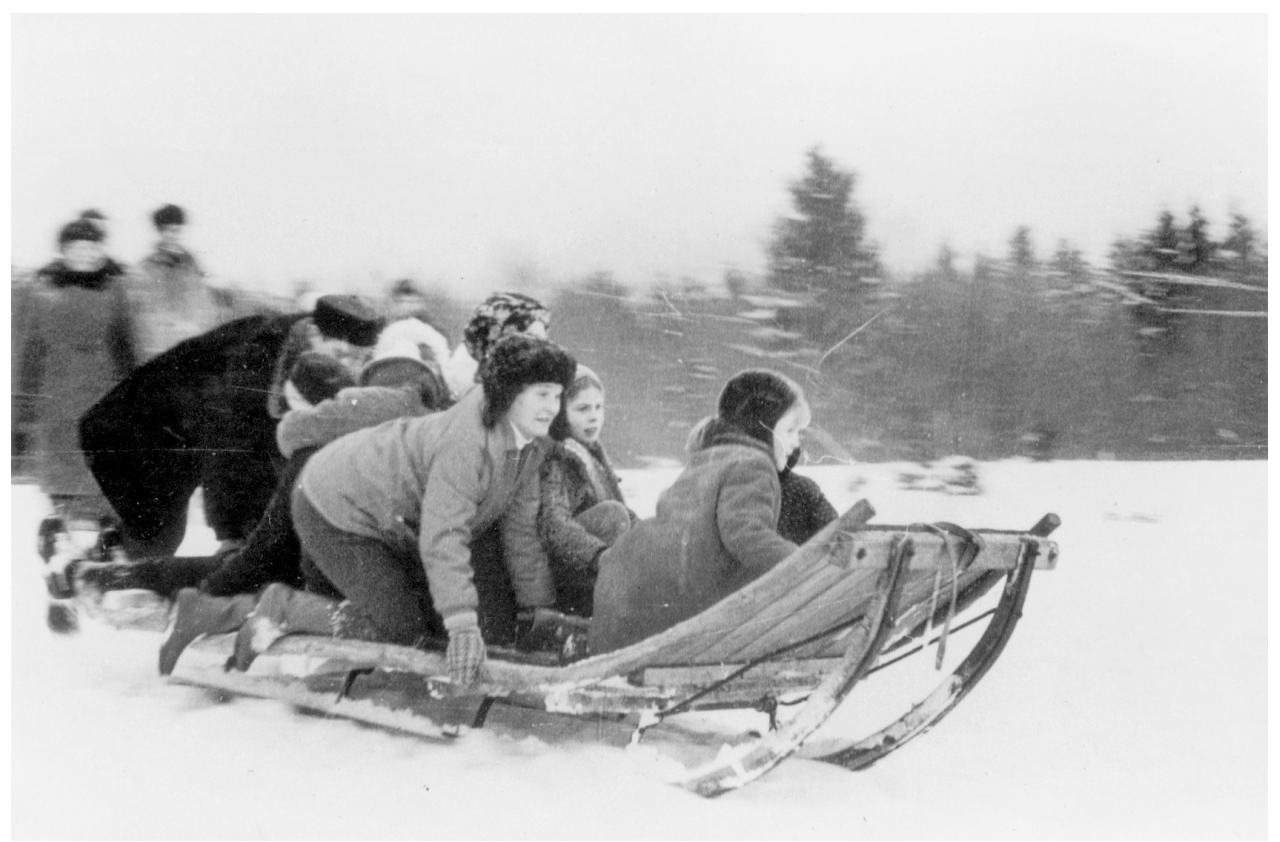

Fig. 1. Sliding on Shrove Tuesday (1955. Collection of Estonian National Museum)

buttocks of feet (LÄTT 1970: 90). Feet were used on plains or on ice. In case a frozen-up lake or river happened to be nearby, a merry-go-round (Collection ERA II 263, 99; Collection ERA II 210, 174/5) was built on the ice. A hole was made into the ice and a pole was stuck upright into it. Then a big wheel was put on the pole and another pole was tied to it. The other end of the pole was tied to a sledge. Horses were also harnessed to sleighs - the longer your slide, the longer your flax grew (Collection ERA II 100, 276).

The other essential tradition on Shrove Tuesday was eating pettitoes. Pettitoes were cooked with beans or peas. Widely known is making a toy - a humming top from pettitoes (Collection ERA II 88, 738/9). Two holes not far from each other were hollowed out in the middle of the pettitoe. Strings were put through the holes, the ends of strings were bound together and when pulling from them the toy began to spin. Pettitoes were even taken to slide. In some places there was a tradition to let the pigs out (Collection ERA II 130, 435) - discs were cut from a round tree and with the help of sticks rolled to the places where pigs were kept in summer. In that way they asked for keeping swine together in the herd.

Between Lady Day (March 25) and St. George's Day (April 23) was Easter, among folk named 'Eggs, Spring or Swing Holidays'. These holidays belonged to the movable feasts. Sunday before Easter - Palm Sunday - is called 'urbepäev' in SouthEstonia and the eastern part of Estonia (where there were Russian and Votian influences) (HIIEMÄE 1991: 26). This name derives from catkins at twigs with catkins 
were brought home early in the morning to wake sleepers by beating with the twigs saying "healthy, healthy". Contact with the living (i.e. not withered) twig was believed to give health and vitality for all summer. Beaters were family members, young men from other households came to beat young women, which was taken as a sign of respect.

While during winter holidays mostly indoor games were played, starting from Easter the large village swing became the main gathering place for village people. Usually every village had its own swing that was put up at Easter every spring. In South-Estonia swinging began at Easter (in some places on Palm Sunday) and ended on Midsummer Day. In North-Estonia the swing was put up on Whitsunday for the whole summer. Swinging during Easter ensured health and luck. In some places people jumped on board - a board placed on a round thick chunk of wood. On the board people jumped up and down (seesaw) (HIIEMÄE 1991: 26).

Young girls took coloured eggs with them to the swing (Collection ERA II 96, 64). The eggs were given to young men for swinging. Twig beaters came themselves to households to ask for eggs. Estonians usually coloured eggs boiling them with onion skins or birch leaves. Sometimes boys made eggs from wood, so they could last cracking. Cracking eggs (Collection ERA II 89, 309) is popular in Estonia even nowadays.

In Setumaa (a region in South-East Estonia) the tradition of gathering at the swing has been preserved until present. They have kirmask (village hop) every weekend beginning from Easter. Setumaa borders on Russia and unlike the other parts of Estonia where the Lutheran church is prevalent, people here are of orthodox faith. That is why their customs and traditions are rather different from those of the rest of Estonia. As an inland region bordering on Russian provinces they have preserved their own old cultural traditions: songs, dances and games. In this region celebrating old festivals - village hops - has survived, with some traditional games, songs and dances.

One of the games very popular nowadays is rolling eggs (Collection ERA II 97, 534). The players use eggs they themselves have painted. The game is mainly played by boys and men on a traditional plot - a natural hillock. The egg rolling downhill has to touch another one lying on the ground. If it does, the player can continue playing with both of them. If it does not, it will remain on the plot. The one who has got most eggs after the game is over, will be the winner. (Fig. 2).

Midsummer Day (June 24) - the holiday opposite to Christmas. On the shortest night of the year everybody gathered at the large swing where they danced and played by the fire. Midsummer Day and Christmas as (summer and winter) solstices are the greatest holidays among the Estonians. Most of the Estonians' magical beliefs and foretokens are connected with these holidays and they have survived till our days. One important Midsummer Day's tradition - making fire - dates from the pre-Christian period; the fire and the firelight were thought to clean and keep off the evils. The fire was made on top of a high pole, so the firelight was visible from far away (HIIEMÄE 1991: 31). However, the fire was often made on the ground and jumping over the fire was very popular: the larger the fire, the more courage, 


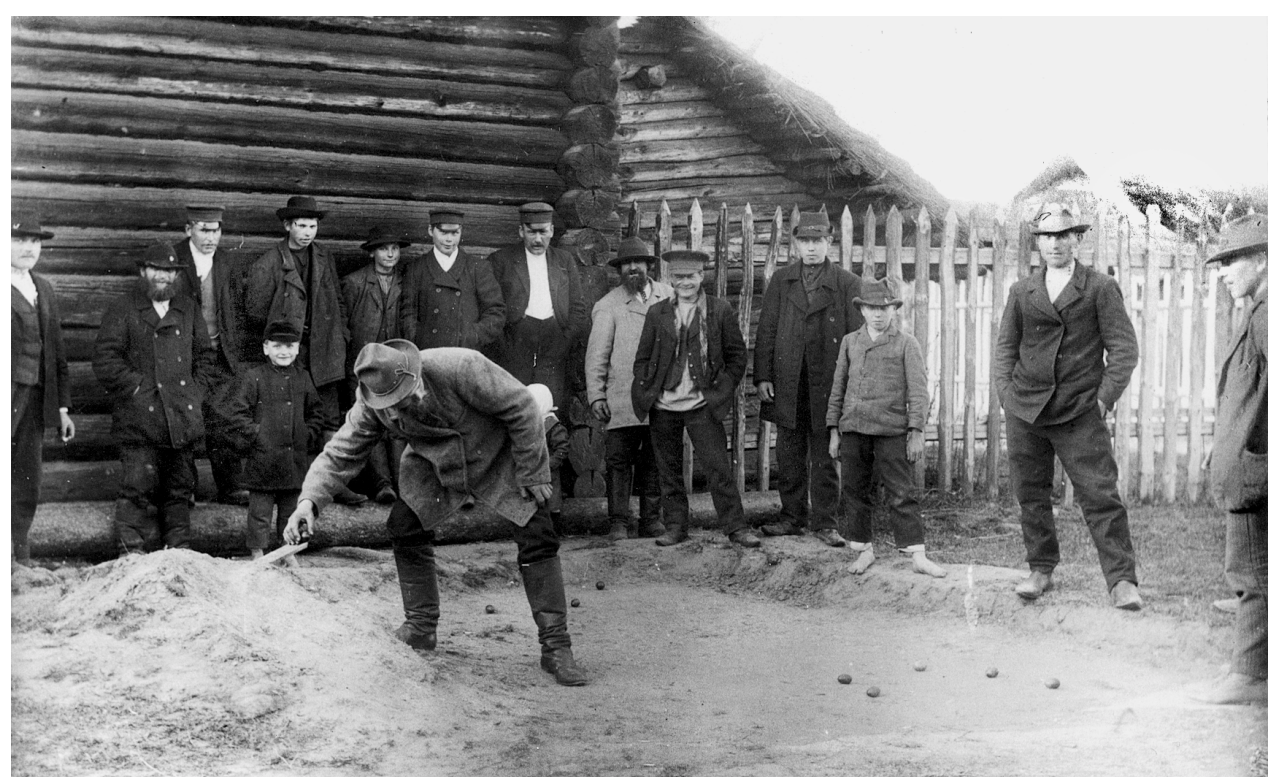

Fig. 2. The folk game 'Rolling eggs' played on the Easter South-East Estonia (Photo by J. Pääsuke 1913. Collection of Estonian National Museum)

strength and skill it demanded. Jumping over the fire often turned out to real competition.

Several round games were played by the fire. Simple moving or dancing accompanied by singing is known all over Estonia (Collection ERA II 211, 221).

The best-known and most-played Midsummer Day game in Estonia was the puppet game. Girls form a circle and sing. Two girls with linens over their heads stand in the centre of the circle. The puppets (under linens) do all that is mentioned in the song. Boys stand by and watch. When the song stops, the puppets must run out from the circle and escape. The boys try to catch them. The game is played until all girls and boys are in pairs. (Collection ERA II 147, 396).

Many of these games require facial expressions and gestures, the movement is often complicated and reminds of folk drama. With facial expressions and gestures the players imitated (domestic) animals or farm-work (e.g. game of a horse). Many games symbolise social relationships (e.g. game of rich and poor).

By the fire strength was tested by pulling a stick crosswise, wrestling, tug of war, gypsy wrestling (Collection ERA II 102, 591), etc. (Fig. 4).

Tug of war is a well-known game even nowadays. It was a team game, with one team on both ends of the rope tugging the other one over a line drawn on the ground. Instead of a line there was sometimes a water body - a stream or a pond and the loser fell in.

Luuri vedamine is a game that has also been played in pubs. Two players participate. They are joined by a loop of rope from behind their necks and they try to pull 


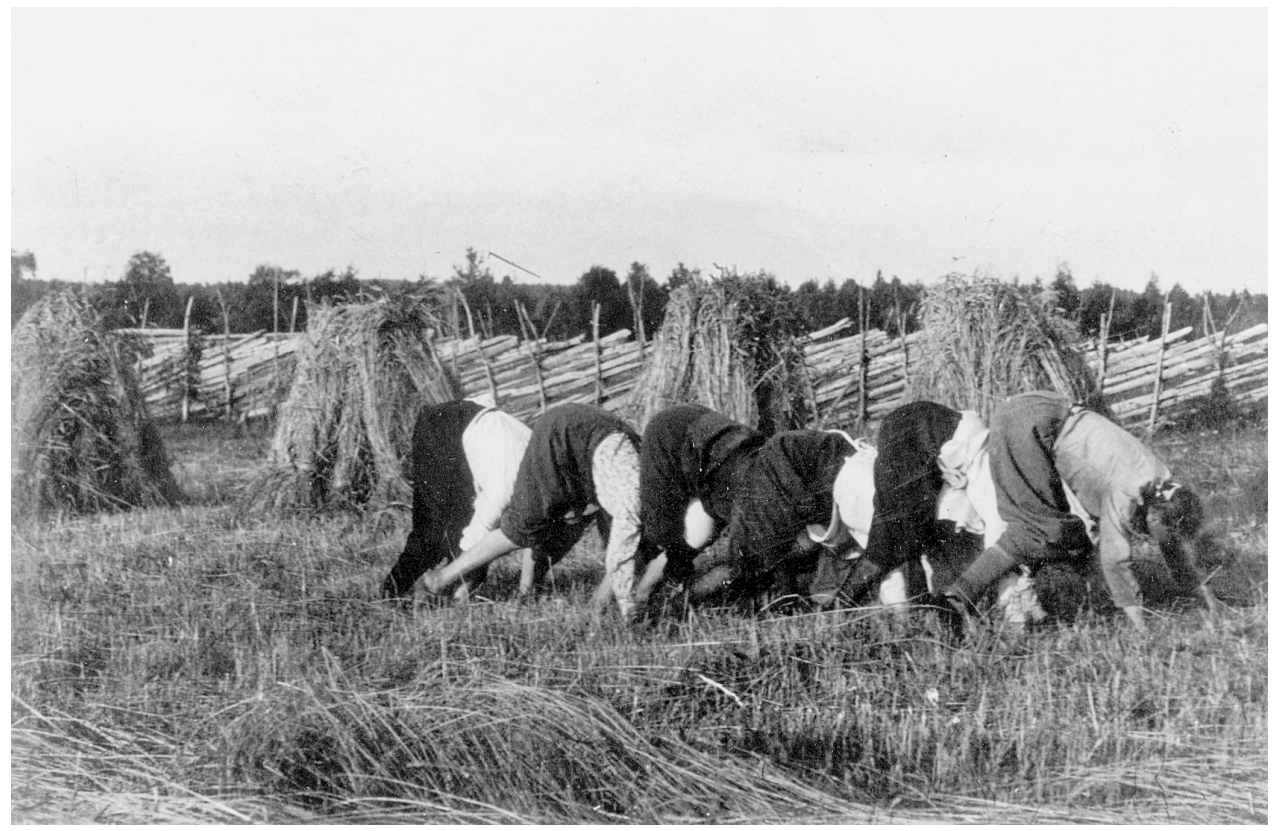

Fig. 3. The folk game 'Rye beetle' from the island Saaremaa (1918. Collection of Estonian National Museum)

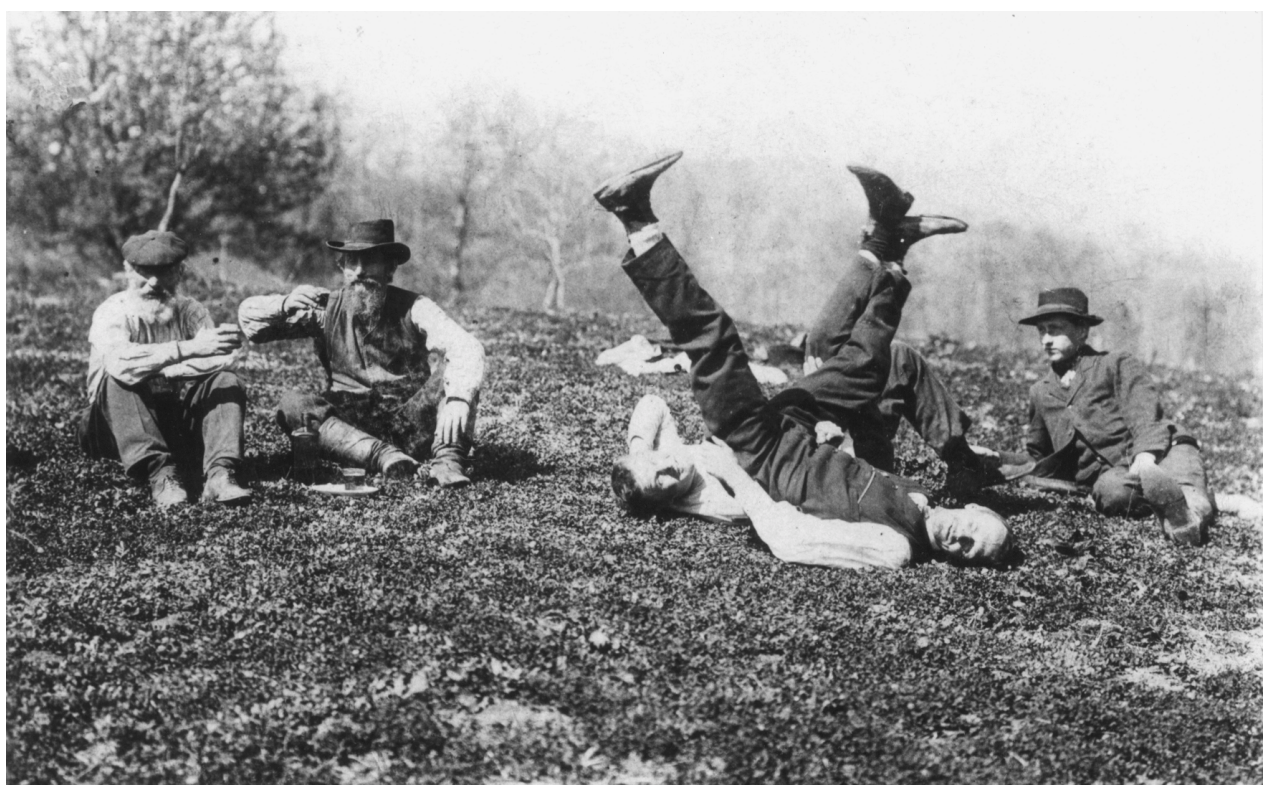

Fig. 4. Gipsy wrestling. Estonian village Alam-Linda in Abchasia SSR. (Collection of Estonian National Museum) 
the opponent up to a certain point (e.g. out of the door). The players can face each other or be back-to-back, in the latter case the starting position is on all fours (KALAMEES 1958: 19).

Another trial of strength was weightlifting. Weights (outside shops or mills), stones, grain sacks, carriages, wheels, anvils and chairs were lifted. The latter were lifted holding them by one leg in a straight stretched hand.

A well-known running game was the last pair. The players stand in pairs in two lines, in front of them stands a single player calling: "sic'em, sic'em, the last pair out". The last players of each line run out in front and try to join their hands. The single player tries to get hold of one of them to form a pair with him. The one remaining single calls the next pair (Collection ERA II 87, 619).

Summer was the busiest time for the Estonian peasant. Summer holidays were usually labour-intensive and only evenings were left for merrymaking. At the summer holidays people ate plenty of food, danced and rested between busy working periods. As the celebrations took place mainly in the open air, several trials of strength and skills were among the games, also games with movements and songs were played. At the holidays in the beginning of summer (St. Peter's Day - June 29, Visitation of the Virgin - July 2) we can meet with traditions similar to the greeting of summer, for example making fire. Summer holidays were often a short 'breathing space' before the next major working period started (St. James's Day - July 25 marked the ending of hay making and the beginning of harvesting). Future crop was predicted (if enough potatoes lasted till St. James's Day, no hunger would come) or weather conditions were observed (if it was raining on the Day of the Seven Brothers - July 10, people thought that is would rain for 7 weeks, when the sun was shining so much that man could get on horse, it was possible to make hay). With certain magical traditions it was hoped to ensure good crop for the next period (on St. Margaret's Day - July 13 - rye field was ploughed, it was thought to protect rye from the ver$\min )$.

For several major works that needed more labour (manure carting, rye harvesting and threshing, digging up potatoes, timber hauling, etc.) bees were held. It was an old form of collective work where people from neighbouring households were asked to come and help. People came to the bee of their own accord although the only pay for it was a day's food and drink. It was a disgrace to refuse participating because it was considered a duty of honour. Bee was also a good chance for young people to meet and look for a mate. For bees better meals were cooked and beer was made. After finishing work people came together. Usually there was a village musician among them. Dancing and playing games (round games, trials of strength, game of forfeits - Collections H III 27, 576/9; H II 7, 799; ERA II 107, 568; H III 27, 583/6) lasted far into the night.

Typical of many Estonian traditional games is connection with certain works. For example, at the end of rye harvesting (according to some facts also manure carting) the symbolic game rye beetle was played (Fig. 3). The players were women, men just watched them playing. In 1930-s when the game was written down, it was taken as a joke, though possibly it had a deeper magical meaning. 


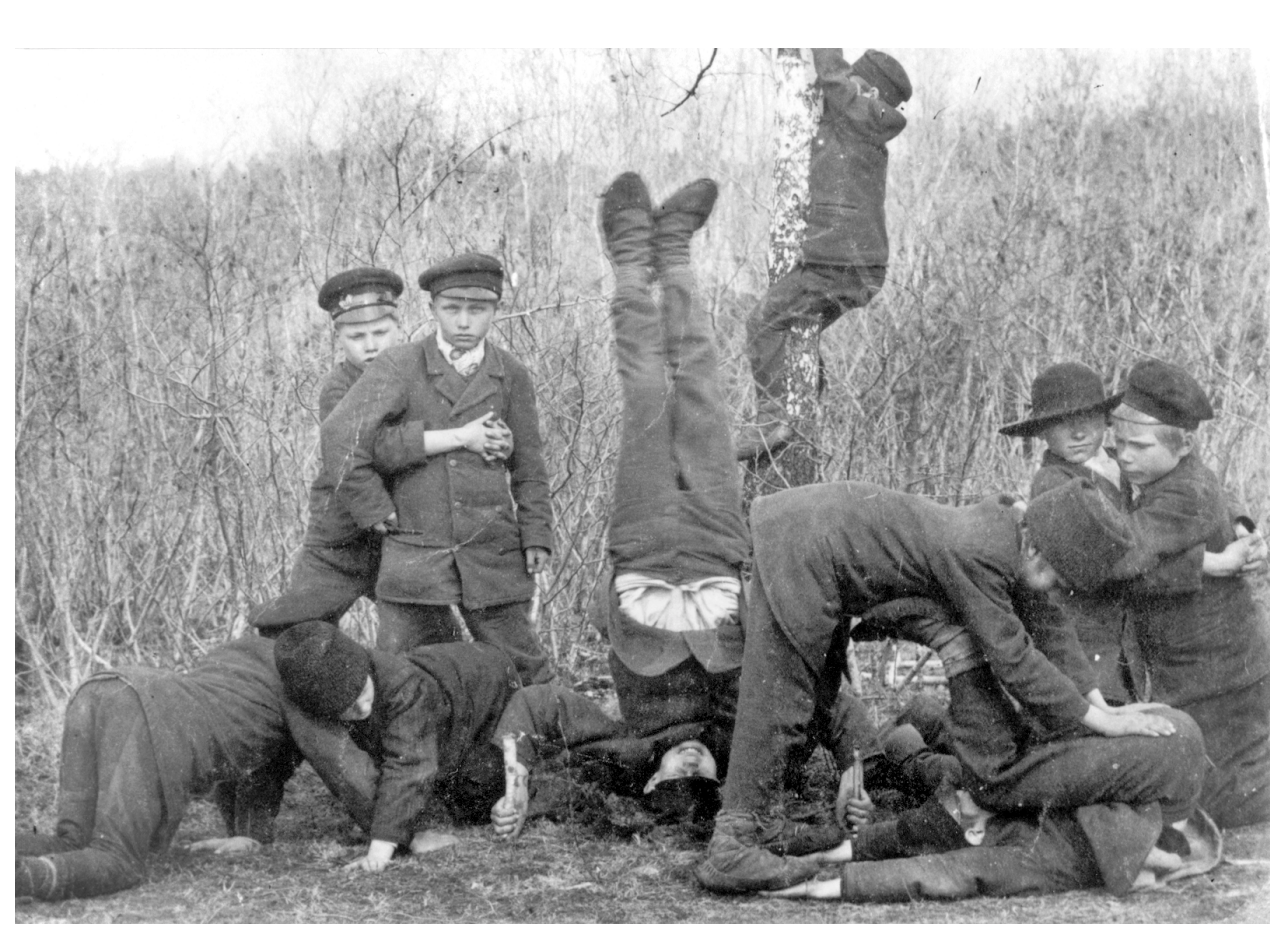

Fig. 5. Demonstration of folk games (Photo by P. Viilup. Collection of Estonian National Museum)

Rye beetle - players moved stoopingly with the head of the following person stuck between the legs of the player in front of her, until they got tired (Collection ERA II 34, 148).

Several games represent imitation of certain works. Fore example throwing bread into the oven, grinding, weaving.

Throwing bread into the oven - one player lies down on his back, bent arms near his head, palms up and raises his legs; the other player steps with his legs on the lying player's palms and puts his own palms on the other's raised soles. The lying player tries to throw the standing player forward to somersault. The standing player tries to land on his feet (Collection ERA II 63, 262), (Fig. 5).

On Michael's Day - September 29 - harvest thanksgiving was celebrated. Contracts with hired servants ended and village youth gathered together to make fire and have a good time. For this day beer and lot of food was made.

St. Martin's and St. Catherine's Days are close holidays with similar traditions. Both on St. Martin's Day's Eve (Nov. 10 - St. Martinus' memorial day) and St. Catherine's Day's Eve (Nov. 25 - St. Catherine's memorial day) young people ran from house to house in disguise, wished luck to fields and cattle, controlled the work of farmer's daughters and children's knowledge of reading and asked for presents meat, malt, beans, peas, scones, sausages, etc. food, which was later eaten in some larger household or pub during the party. 
St. Martin's Day was usually considered the beginning of winter. From St. Martin's Day to St. Catherine's Day was time of going over from the summer period into winter, it was necessary to finish outdoor work and begin with indoor work.

St. Martin's Day was rather a men's holiday, St. Martin's beggars were (especially in the earlier period) young men, who wore nasty, dirty and shabby clothes (Collection ERA II 263, 165). St. Catherine's Day is known as a women's holiday and St. Catherine's beggars were mainly young women in clean, white and beautiful clothes, often they wore hats and veils. This is an analogy with nature: snow defeating St. Martin's Day's mud. Beggars moved from household to household - their leader was St. Martin's father or St. Catherine's mother, all the other members were children, animals or different craftsmen. The ceremony of begging followed a certain pattern - in singing they asked letting in, wished luck to the household, asked for presents and thanked (or cursed when no presents were given or they were not good enough).

St. Martin's party was held later because of making dishes from the presents (for example beer was made). The main idea of the beggars was to share the harvest feast with the other village people and in that way ask for luck and profit for next year. Mainly in West-Estonia, but also in some other places these parties were held as St. Martin's or St. Catherine's weddings (PÄss 1934: 73), which had the same traditions as real weddings had. So on St. Martin's and St. Catherine's Days the village folk gathered together and younger people danced, played and amused. The most popular game played on these days was gypsy wrestling (PÄss 1934: 76). Two wrestlers lie on their backs, side by side, with their heads in the opposite directions. They raise their - inner - legs and hook them up, trying to turn the opponent over his head (Fig. 4).

Weddings were usually held between St. Martin's Day and Christmas and it was one of the most important family gatherings. Wedding as a whole was a play with certain traditions and lasted for several days (2-3 or even the whole week). Usually there were about hundred guests, often even more.

Prelude of the wedding was the marriage proposal. During the time between proposal and marriage the bridal chest was filled. On Thursday or Sunday evening country girls (bridesmaids) helped the bride to complete it.

Usually half of the wedding party was held at the bride's home and the other half at the bridegroom's home.

At the wedding ceremony the bride and the bridegroom were only formally the main persons. The couple's parents played no important role either. The main characters at the wedding party were the best man (representative of the bridegroom's guests) and 'kaasanaine' (representative of the bride's guests). Both of them had their own escort from unmarried young men and women. Nearly every guest had a role to play. The most important person in the wedding game and jokes was the 'bride's brother'.

The wedding began with the gathering of the guests - the bride's relatives at her home and the bridegroom's relatives at his home. The bridegroom's relatives all together went for the bride - this procession was called 'saajarong'. This step in the 
wedding included many songs. Demanding the bride was one by singing and asking each other puzzles, accompanied by jokes.

The first part of the wedding was ended by the bride's leaving from her home. Guests sang to bride and bridegroom instructions for their future life.

During the wedding-ride several predictions and magical traditions were followed and usually there was much noise (shouting, shooting, etc.).

The bride's arrival to her new home included several traditions, which had to ensure happy and wealthy living. When everybody had arrived, the horse bow was taken from the horse harnessed to the bride's carriage and thrown to the roof of the house (KALAMEES 1958: 299). The one who did it was the bridegroom's father, groomsman or somebody from the wedding guests. In reward he got a pair of mittens from the bride. An important event was introducing the new household to the bride. The bride left gifts everywhere - a belt to the well, mittens, socks to the shed, etc. These were picked up by the bridegroom's mother.

On the first day at the bridegroom's home took place the most important event in the wedding tradition (in Estonian wedding it was more important than the ceremony in church) - called 'capping or coifing the bride'. A woman's headgear (linen kerchief, scarf, cap, head dress) was put on the bride's head. Usually it was done by the bridegroom's mother. 'The capper' combed the bride's hair and then hit her head with the headgear and said: "Forget the sleep, remember the mind, remember the man!" then the bride was capped. It was done three times: the first and the second time the headgear was put on one side and bride shook it down (instead of the headgear it could be the bridegroom's cap). Only at the third time was the headgear kept on head. During the ceremony the bride had to cry, then she would not cry in the future (TEDRE 1991: 63).

Besides the traditional ceremony joyful parlour dances and games (the last pair, holding the glory of homeland, etc.) were played on the second day. Men had also trials of strength (finger hook, gripping hands, gipsy wrestling etc. (Collection ERA II 107, 563; ERA II 266, 442)).

The second day was ended with 'throwing the bride to sleep' - bride and bridegroom gave their roles to the so-called 'new couple', who had to play 'the couple's' role after the real couple had gone to sleep. This was done in the round game bridal wreath (Collection ERA II 131, 142).

The most important tradition on the last day of wedding was sharing the bridal chest - the bridegroom's relatives all got mittens, socks, shirts, etc. made by the bride. Sometimes the guests gathered money for the bride during this ceremony.

The ceremony of gathering money, well-known all over the country, was called 'cleaning the table' (Collection ERA II 93, 100). After finishing eating on the third day, the guests left some small change under the plates or on the table. The best man or the hostess wiped crumbs and money to sieve. These were signs for ending the wedding party.

Adults had time for entertainment only on holidays, but for children playing games was part of their everyday life. However, children had to start working at an early age. The first job for them was tending the cattle. Older children usually had to 
teach the younger ones how to do it, nevertheless there was enough time left for playing as well. These were mainly games requiring a lot of moving around: hideand-seek (Collection ERA II 186, 332/3; ERA II 100, 49), racing (Collection H III 27, 583/6), climbing (Collection ERA II 108, 47), chasing (Collection ERA II 107, 568). At racing or climbing (Collection ERA II 107, 575) the prize was usually a tasty snack put at a certain distance. Boys' favourite games were wrestling (Collection ERA II 129, 69; ERA II 88, 311/2) (Fig. 5) and trials of strength. Girls played various games with stones (Collection ERA II 96, 222) and also round games. Various games with sticks (clubs) (Collection ERA II 105, 426) - Driving a goat into the cote, Kurnimäng, etc. (Collection ERA II 107, 653) - were popular all over the country.

Kurnimäng (a game played with six cylindrical wooden pins) - This game is known all over the world. Patterns made of wooden pins are knocked out of a square drawn on the ground with a cudgel (Collection ERA II 177, 306/9; ERA II 87, 167).

Turn in the games was decided by casting lots (Collection ERA 149, 581/2). Several types of lots were known - verse lots, repeated reading, etc. Lots could also be cast by throwing and catching stones, sticks, etc., running towards a certain object, striking matches, etc. Stick lot - one player throws a stick into the air. He himself or some other player catches it with his right hand. Now all players hold the stick in their right hand. The player, whose hand is the last, gets the best position in the game (Collection KKI).

The most reined expression of a game is sport. Popular sports practised in the past have found expression in folklore. So the national epic "Kalevipoeg" describes lifting and carrying weights, throwing stones, pulling a stick crosswise, wrestling, swimming, high jumping.

Sport as we know it nowadays spread among the Estonians in the second half of the 19th century. At first mainly such branches of heavy athletics as national wrestling, lifting weights, etc. were practised. The Estonian popular wrestling had three main holds:

- wrestling with a hold around the waist - the contestants clasp each other with one hand over the arm and with the other from under the arm and join their fingers on the other's back.

- grapple - the contestants seize each other by the lapels.

- waistband wrestling - the contestants hold each other by the waistband (Collections H II 66, 467/8; ERA II 300, 457; ERA II 91, 565/6).

The rules were agreed on before starting and the contestants acted as referees themselves.

The best known Estonian game that preceded to the sport games played with a bat (stick, club, etc.) and a ball, etc. was driving a goat into the cote.

Driving a goat into the cote - A large hole (cote) is made into the ground and around it, at a distance of 4-7 metres, a smaller hole is made for each player. Each player has a stick and protects his hole by keeping the stick in it. The player without his own hole is the drover. Goat (a wooden ball) has to be driven into the cote. The players standing at their holes on a circle try to keep the goat away from the cote. In 
case the drover is able to thrust his stick into any hole, the player whose hole it was will be the next drover. If the drover succeeds in driving the goat into the cote, all the players change places. The one without a hole will be the next drover (Collection ERA II 88, 420; ERA II 104, 312/3).

Purposeful physical education in Estonia started in the 1870s when gymnastics was introduced into school programmes. The first Estonian textbook in this field compiled by J. KURRIK (1879) gives a wide choice of exercises as well as some general methodogical principles many of which are recognised even nowadays.

Organised sports activities in Estonia were connected with founding sports circles and societies. The first of the Baltic-German sports societies was a gymnastics society "Revaler Turnverein" founded in Tallinn in 1863. In the first sports circles people mainly practised heavy athletics as this had the strongest national roots. The sports circle called "Tallinn Club of Fun Athletes" founded by Gustav BOESBERG in 1888 gave a whole range of prominent athletes, the most famous of whom was world champion in wrestling, Georg LURICH. The first officially registered sports association in Estonia was "Saadjärve Cyclists' Society" founded in 1896. Heavy athletics and cycling were the most popular sports at that time. This did not mean these were the only branches practised. In the first decades alongside with gymnastics, rowing and skating people went in for light athletics, swimming, figure skating, skiing, etc. Of modern sport games tennis became known in Estonia first, although football overpowered it in practice (since 1909). In the course of time the popularity of sport games (ice hockey, hockey, basketball, volley-ball, table tennis, baseball, bowling, etc.) has been changing depending on fashion and practising conditions.

Nowadays the most popular sports in Estonia are basketball, light athletics, volley-ball, cycling, football, skiing and swimming.

More than 60 medals awarded to the Estonians at the Olympic Games show that the one-million Estonian people are rightfully called sports-loving people who besides intellect also respect physique.

\section{PHOTO COLLECTIONS}

$\mathrm{E} \quad=$ Collection of Johann Matthias EISEN

ERA $=$ Collection of the Estonian Folklore Archives

$\mathrm{H}=$ Collection of Jakob HURT

KKI $=$ Folklore Collection of the Estonian Language and Literature Institute

\section{LITERATURE}

EISEN, Matthias Johann

1931: Jõuluõled. Tartu. In: Eesti Rahva Muuseumi Aastaraamat VI. 67-80. (Christmas Straw. In: Yearbook of the Estonian National Museum).

HIIEMÄE, Mall, ed.

1981: Eesti rahvakalender II. Tallinn. (Estonian Folk Calendar II).

1984: Eesti rahvakalender III. Tallinn. (Estonian Folk Calendar III).

1985: Eesti rahvakalender IV. Tallinn. (Estonian Folk Calendar IV). 
HIIEMÄE, Mall, ed.

1991: Eesti rahvakalender V. Tallinn. (Estonian Folk Calendar V).

HIIEMÄE, Mall

1991: Rahvakalendrist. Tallinn: In (TEDRE, Ülo, ed.) Vanadest eesti rahvakommetest. 5-35. (About folk calendar. In: Old Estonian folk customs).

HIIEMÄE, Mall, ed.

1995: Eesti rahvakalender VI. Tallinn. (Estonian Folk Calendar VI).

1995: Eesti rahvakalender VII. Tallinn. (Estonian Folk Calendar VII).

KALAMEES, Aleksander

1936: Valik eesti rahvamänge. Tartu. (Selected Estonian Folk Games).

1958: Eesti rahvamängud. Tartu. (Estonian Folk Games).

1973: Eesti rahvamänge. Tallinn. (Estonian Folk Games).

LÄTT, S. ed.

1970: Eesti rahvakalender I. Tallinn. (Estonian Folk Calendar I).

MOORA, Harri-MoORA, Aliise

1964: Volkstümliche Zeitrechnung, Arbeitszyklen, Gedenk- und Festtage des Jahres. Tallinn. In: (MOORA, Harri-VIIRES, Ants, eds) Abriß der estnischen Volkskunde, 236-249.

PÕLDMÄE, Richard-TAMPERE, Herbert

1938: Valimik eesti rahvatantse. Tartu. (Selected Estonian Folk Dances).

PÄSS, Elmar

1931: Lihaheide Eestis. In: Eesti Rahva Muuseumi Aastaraamat VI. 5-40. (Shrove Tuesday in Estonia. In: Yearbook of the Estonian National Museum).

1934: Mardipäeva mängudest. Tartu. In: Eesti Rahva Muuseumi Aastaraamat VIII. 71-89. (Games on St. Martin's Day. In: Yearbook of the Estonian National Museum).

RAUDKATS, Anna

1933: Tütarlaste mänguraamat. Tartu. (Game Book for Girls).

RÄNK, Gustav

1996: Vana eesti rahvas ja kultuur. Tartu. (Old Estonian People and Culture).

TAMPERE, Herbert

1960: Eesti rahvalaule viisidega II. Tallinn. (Estonian Folk Songs with Melodies).

TEDRE, Ülo

1991: Elutähtpäevadest ja nendega seotud kommetest. Tallinn: In: (TEDRE, Ülo, ed.) Vanadest eesti rahvakommetest. 36-76. (Festive Days of Life and Customs connected with them. In: Old Estonians Folk Customs).

VIIDALEPP, Richard-TAMPERE, Herbert

1964: Volksdichtung und -musik. Tallinn. In: (MOORA, Harri-VIIRES, Ants, eds) Abriß der estnischen Volkskunde. 275-300. 